\title{
The Genetic Relationship and Phenotypic Expression of Mutations Endowing Pneumococcus with Resistance to Erythromycin
}

\author{
By A. W. RAVIN AND V. N. IYER \\ Department of Biology, University of Rochester, Rochester 20, New York, U.S.A.
}

(Received 17 March 1961)

\section{SUMMARY}

Five spontaneous erythromycin resistance mutations arising independently in a pneumococcal strain have been studied. Three distinct levels of resistance are represented by these mutants $(0 \cdot 1,1 \cdot 0$, and $\mathbf{1 0} \cdot 0 \mu \mathrm{g}$. erythromycin per ml.). The mutations conferring resistance can be transferred to the sensitive parental strain through transforming DNA preparations. The transfer is discrete, in that the full level of resistance of the donor strain is always conferred upon the recipient. The length of time required for phenotypic expression of a mutation acquired by transformation depends on the particular marker.

A mutation in a given strain may either be replaced by or combine with a different mutation transferred from a donor DNA preparation. In the case of combination, the DNA of the recombinant is capable of transferring each of the mutations as well as the entire complex of mutations possessed by the recombinant. The frequency of transfer of the complex demonstrates the degree of linkage of the separable mutations. A group of mutations in a given recombinant strain may either display antagonistic, synergistic or non-synergistic effects on the phenotype.

Reverse mutations towards erythromycin-sensitivity generally involve alteration at the originally mutated sites, or at very closely linked sites.

\section{INTRODUCTION}

In recent years the fine structure of genetic material has been investigated in great detail in a number of micro-organisms (Pontecorvo, 1952; Pritchard, 1955; Benzer, 1955; Demerec, 1956). These investigations have shown that the particular segment of genetic material concerned with a specific function of the organism is capable of undergoing numerous mutations situated at different sites separable by genetic recombination. The order of these mutations in a linear array can generally be determined by the additivity (or near-additivity) of the frequencies of recombination observed to occur in crosses between the various pairs.

The analysis of genetic fine structure has been extended to deoxyribonucleic acid (DNA) transforming factors (Hotchkiss \& Evans, 1958; Lacks \& Hotchkiss, 1960; Ravin, 1960; Ephrati-Elizur, Srinivasan \& Zamenhof, 1961; Rotheim \& Ravin, to be published). The molecule of DNA has been found to be large and complex enough not only to bear regions concerned with different functions of the organism (Hotchkiss \& Marmur, 1954; Goodgal \& Herriott, 1957), but also numerous mutable sites 
separable by recombination within each region (Ephrussi-Taylor, 1951; Ravin, 1960; Lacks \& Hotchkiss, 1960; Ephrati-Elizur et al. 1961; Rotheim \& Ravin, to be published). Recombinable mutations borne by the same molecule of DNA can often be arranged in a linear order (Hotchkiss \& Evans, 1958; Ravin, 1960; Lacks \& Hotchkiss, 1960; Ephrati-Elizur et al. 1961).

This report concerns the genotypic and phenotypic analysis of five independent mutations conferring resistance to erythromycin on pneumococci. It has been known (Haight \& Finland, 1952b) that mutants arising spontaneously generally resist only a relatively low concentration of erythromycin; strains enhanced in their level of resistance can be obtained by repeated selections at gradually increasing concentrations of the antibiotic. Such step-by-step accretion of resistance is similar to that observed with penicillin (Demerec, 1945; Hotchkiss, 1951). The mutations described in this paper were found either to replace or combine with each other in transformation reactions. Some combinations led to enhanced levels of resistance, although non-synergistic and antagonistic interactions were also observed with certain groups of combined mutations. All of the mutations, however, like those affecting other functions previously studied, behaved as linked factors, that is, as factors occupying different sites of the same molecule of DNA.

Most effective against Gram-positive cocci and diphtheria bacilli (Haight \& Finland, 1952a), erythromycin may be either bacteriostatic or bactericidal, depending upon the concentration. At the concentrations used in the present experiments, its action was principally killing. Like penicillin, its bactericidal action requires active multiplication of the treated strain (Haight \& Finland, 1952c).

\section{METHODS}

Organisms and genetic markers. The erythromycin sensitive strain of Pneumococcus used in these experiments is $\mathrm{Rx}$, a capsule-deficient mutant derived from a type III encapsulated strain (SIII-N) that had been previously produced by transformation (Ravin, 1959). The Rx strain does not form visible or microcolonies when plated on blood agar containing more than $0.01 \mu \mathrm{g}$. erythromycin per ml. (Table 1). Green (1957) obtained a number of spontaneous erythromycin resistant mutants by plating $10^{9} \mathrm{Rx}$ bacteria on a blood agar medium containing $1 \mu \mathrm{g}$. erythromycin per ml. Twenty large colonies appeared after $72 \mathrm{hr}$. incubation at $37^{\circ}$. Strains derived from three of the twenty mutant colonies isolated by Green were examined in the studies reported here; they contain, respectively, the mutations ery-r2, ery-r3 and ery-r5. The strains derived from two of the other colonies isolated by Green, originally resistant to at least $1 \mu \mathrm{g}$. erythromycin per ml., subsequently reverted to the wildtype erythromycin sensitive condition during the transfer of stocks. They reverted before it was possible to determine their genotypic relationship to the three mutants just mentioned. These reverted strains are referred to as E21-rev. and E24-rev.

Subsequently, two additional spontaneous mutants of independent origin were obtained. One of these was a mutant colony obtained by plating a culture of strain SIII-I b (Ephrussi-Taylor, 1951) on blood agar containing $0 \cdot 1 \mu \mathrm{g}$. erythromycin per ml. Upon isolation, this strain was found, by the method of direct plating described below, to be incapable of growing in the presence of erythromycin at concentrations greater than $0 \cdot 1 \mu \mathrm{g}$. per $\mathrm{ml}$. The genetic factor responsible for the 
erythromycin resistance of this strain was transferred to the $\mathbf{R x}$ strain by exposing the latter to the DNA extracted from a culture of mutant cocci. This transformed strain of $\mathrm{Rx}$ proved to have the same level of resistance as that of the original SIII-1 b mutant. The mutation contained in this strain is referred to as ery-r6. The other spontaneous mutation was obtained by plating a culture of $R 6 R$, a derivative of the capsule-deficient strain R36 A (Ravin, 1960), on a blood agar medium containing $0.1 \mu \mathrm{g}$. erythromycin per $\mathrm{ml}$. One of the colonies that developed upon incubation was found to consist of cocci capable of resisting a much higher concentration of erythromycin than that used for selecting the mutant. The mutation responsible for this high level of resistance, referred to as $\operatorname{ery}-r \%$, was subsequently transferred by means of transformation to the $\mathbf{R x}$ strain. The $\mathbf{R x}$ transformants thus produced possessed the same level of resistance as that of the original $\mathbf{R} 6 \mathbf{R}$ mutant (Table 1).

Table 1. Maximum level of resistance of mutants bearing different ery-r mutations, including several recombinant types, and the time required for phenotypic expression of resistance newly acquired by transformation

Category

1. Mutations of strain $\mathbf{R x}$

2. Recombinations in strain $\mathbf{R x}$

3. Mutations in other strains

4. Wild-type (Rx)
Marker (s)

ery-r6

ery-r2

ery-r 3

ery-r 5

ery-ry

ery-r2-r6

ery-r3-r6

ery-r2-r3

ery-r6-ry

ery-r5-r7

ery-r2-r3-r 5

ery-r6 in strain SIII-1 b $e r y-r 7$ in strain $\mathbf{R 6 R}$

ery-s2-s3-s5-s6-s7
Time (hr.)

Concentra- at which

tion of ability

erythro- to resist

mycin challenging

( $\mu \mathrm{g} . / \mathrm{ml}$.) concentra-

used to tion is ex-

challenge pressed in

trans- all trans-

formants formants ( $\mu \mathrm{g}$. erythromycin./ml.)

$0 \cdot 1$

$1 \cdot 0 \pm 0 \cdot 2$

$1 \cdot 0 \pm 0 \cdot 2$

$1 \cdot 0 \pm 0 \cdot 2$

$10 \cdot 0 \pm 5 \cdot 0$

$5 \cdot 0$
$15 \cdot 0$
$40 \cdot 0 \pm 10 \cdot 0$
$10 \cdot 0 \pm 5 \cdot 0$
$10 \cdot 0 \pm 5 \cdot 0$
$15 \cdot 0 \pm 5 \cdot 0$
$0 \cdot 1$
$10 \cdot 0 \pm 5 \cdot 0$
$0 \cdot 01$

$0.075 \quad 1$

$0 \cdot 25 \quad 1$

$0.25 \quad 1$

$0 \cdot 25 \quad 1$

$\{0 \cdot 1 \quad 3$

$\{5 \cdot 0>5$

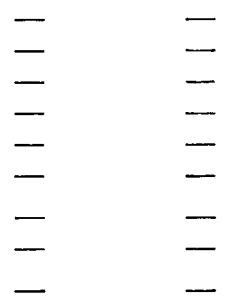

The variability indicated for certain mutations and recombinations expresses approximately the highest and lowest maxima observed in a series of similar tests.

At various times the ery-r markers have been transferred into closely related strains (e.g. SIII-1, SIII-2, Rz, etc.; see Ravin, 1959) which differ from Rx only in the possession of a different mutation within the type III capsule locus (Ravin 1960). The DNAs obtained from such transformed strains have been used in some of the transformation experiments described below.

An additional genetic factor was occasionally also present in the particular donor strain from which the transforming DNA was prepared. This additional factor was 
str-r1 (Ravin, 1956; Bryan, 1961), which confers the ability to resist up to $6000 \mu \mathrm{g}$. streptomycin per ml. Thus, DNA preparations generally contained, in addition to the ery-r factor being investigated, either str-r1 or $\mathrm{caps}^{+}$, the wild-type allele of the mutated factor $\left(\mathrm{caps}^{-}\right)$responsible for the capsule deficiency in the $\mathbf{R x}$ strain (Ravin, 1960), or sometimes both factors. Neither of these factors is linked to any of the ery-r factors described in these experiments (Ravin, 1960). The additional genetic factor served as a control in certain experiments; the successful transfer of this factor showed that the failure to obtain alterations in the level of erythromycin resistance of the treated recipient strain could not be ascribed either to incompetence of the recipient culture or inactivation of the transforming preparation.

The genetic factors in the sensitive $\mathrm{Rx}$ strain which are homologous to those in the respective erythromycin-resistant and streptomycin-resistant mutant strains are symbolized as follows: $e r y$-s, str-s.

It should be pointed out that a factor $(d e p)$ linked to the streptomycin-resistance marker str-r1, which lowers the frequency of genetic integration of the latter into the genomes of certain recipient strains, is of no significance in the experiments to be reported here since the $d e p$ factor has no effect when transferred into $\mathrm{Rx}$ bacteria (Green, 1959; M. B. Rotheim, to be published).

Transforming preparations. The method of preparing the DNAs used in these experiments is essentially identical to that described by Ephrussi-Taylor (1951). The DNAs were preserved by solution (at concentrations from 0.01 to $0 \cdot 1 \%, \mathrm{w} / \mathrm{v}$ ) in a physiological saline solution $(0.15 \mathrm{M}-\mathrm{NaCl})$ buffered with phosphate $(\mathrm{pH} 7)$ and storage at $4^{\circ}$. Saturating concentrations of DNA were used in all experiments.

Media. Three media, originally described by Ephrussi-Taylor (1951), were used in these experiments. Medium 1, which consists of $1 \%(w / v)$ Neopeptone (Difco), $0.4 \%(\mathrm{w} / \mathrm{v})$ yeast extract (Difco) and $0.86 \%(\mathrm{w} / \mathrm{v}) \mathrm{NaCl}$ in demineralized water, was used for growing cultures to be used as sources of transforming DNA. High yields of bacteria were obtained by the addition of an excess of glucose $(0 \cdot 63 \%$, $\mathrm{w} / \mathrm{v}$, in final concentration) and intermittent additions of $\mathrm{N}-\mathrm{NaOH}$ to neutralize the acid produced in the course of growth.

Medium 2 was the standard plating medium. In addition to the ingredients present in medium 1, it contained $1.5 \%(\mathrm{w} / \mathrm{v}$ ) agar (Difco or BBL), $0.033 \%(\mathrm{w} / \mathrm{v})$ glucose and $2 \%(\mathrm{w} / \mathrm{v})$ sterile defibrinated sheep blood (Cappel Labs). Glucose (sterilized separately by filtration) and sterile blood were added to the rest of the autoclaved and cooled medium just before the pouring of plates. Plates were poured and, before use, they were dried overnight by incubation in a forced air (CENCO) incubator at $37^{\circ}$. To media to be used for the assay of antibiotic-resistant mutants or transformants were added, at the time of addition of blood and glucose, an appropriate amount of the stock solution of the antibiotic in question. The usual concentrations of antibiotic used in the screening of resistant bacteria produced by transformation were $0 \cdot 1,0 \cdot 25$ and $5 \cdot 0 \mu \mathrm{g}$. erythromycin per $\mathrm{ml}$. and $100 \mu \mathrm{g}$. streptomycin per $\mathrm{ml}$. In certain transformation experiments, other concentrations were used, and these will be specified below. The antibiotic products used were obtained as erythrocin lactobionate (Abbott) and streptomycin sulfate (Lilly).

Medium 3 consisted of inorganic salts, Neopeptone (Difco), an extract of bovine serum, charcoal-adsorbed yeast extract, and a growth-limiting concentration of glucose dissolved in glass-distilled demineralized water. Transformations and stock 
transfers were carried out in this medium. For the transfer of stocks $\mathbf{0 . 1} \mathbf{~ m l}$. of sterile defibrinated rabbit blood (Cappel Labs.) was added per $5 \mathrm{ml}$. of medium. Cultures in any of these media were incubated at $37^{\circ}$.

Assay of antibiotic resistance. The maximum level of resistance of an isolated strain was determined in one of two ways: (A) Direct plating-A sample is taken from a medium 3 culture and appropriately diluted in $1 \%(\mathrm{w} / \mathrm{v})$ Neopeptone (Difco); similar samples from the dilution are spread by means of a bent glass rod over the surface of plates of previously dried medium 2, some of which are devoid of antibiotic ('plain agar') while others constitute a series of increasing concentration of antibiotic. That concentration of antibiotic above which the final number of colonies appearing is significantly less than that observed in plain agar is arbitrarily chosen as the maximum level of resistance of the strain being tested. (B) Streak testingin the cases where one must test a large number of colonies arising from a culture treated with transforming DNA, the colonies are first transferred by isolating them individually with a needle and spreading over the surface of plain agar. Some of the growth arising on these plates is then transferred, either by streaking with a needle or by replicating a velvet impression (Lederberg \& Lederberg, 1952), on to a series of plates, each containing a different concentration of antibiotic. Similar streaks are made at the same time to plain agar as a control for the viability of the growth being tested. While streak testing has certain advantages for the examination of a large number of strains, it has the disadvantage that the application of dense populations of bacteria on to a given region of an antibiotic-containing medium occasionally gives spurious results. Some physiological mechanism allows the crowded population, or part of it, to resist higher concentrations of antibiotic than the individual cocci are capable of resisting in isolation. Streak tests thus often need to be rechecked and verified by the use of the method of direct plating.

Cultures that have been exposed to transforming DNA were analysed in the following way. Appropriately diluted samples of such cultures were plated on plain agar, on agar containing various concentrations of erythromycin, and, where necessary, on agar containing $100 \mu \mathrm{g}$. streptomycin per ml. The titres of total viable bacteria (obtained from the plain agar plates) and of bacteria resistant to the given concentrations of antibiotic were determined from the counts of colonies formed after 48 or $72 \mathrm{hr}$. of incubation (in any case, at a time beyond which continued incubation brings forth no more colonies). The frequency of resistant transformants, expressed as the fraction of the total number of viable cocci capable of resisting a given concentration of antibiotic, can then be calculated. The maximum level of resistance of colonies growing in agar containing a certain concentration of antibiotic was determined by isolating such colonies and testing the isolates by either direct plating or streak testing.

Transformation. In a transformation experiment a recipient strain of a given genetic constitution was exposed to the DNA extracted from a donor strain of different genetic constitution. Recombinant bacteria containing some of the genetic factors of the donor and some of the recipient were sought among the progeny of the treated recipient bacteria. In a real sense, therefore, a transformation experiment is equivalent to a 'cross' between two individuals of different genotype.

The transformation was carried out in one of the following ways. (A) Long-term experiment: in this type of experiment, the recipient cells are exposed to DNA for 
a relatively long period of time lasting many generations. The transforming DNA remains in contact with the cells during the time in which they are becoming competent to react with DNA, and for several generations after the effective contacts have occurred. It is a simple procedure to use when certain qualitative results are desired (such as the production of any recombinants at all from a given 'cross'). The procedure consists in transferring into medium 3 containing the appropriate DNA plus $0.2 \%(\mathrm{w} / \mathrm{v})$ bovine serum albumin (Armour Fraction V), a small number of cocci of the desired recipient strain from a medium 3 culture which has just stopped growing. The initial bacterial density is arranged to be about 500 per $\mathrm{ml}$; there is no appreciable lag following such a transfer. After 7 to 11 generations of growth (3$\frac{1}{2}$ to $5 \frac{1}{2} \mathrm{hr}$. after inoculation), the cocci become competent and react with the DNA present in the medium (Ravin, 1956). The culture is then plated after growth is terminated by the exhaustion of glucose ( $10 \mathrm{hr}$. after inoculation). The time interval between effective contact of competent cocci with transforming DNA and the plating of the culture is, in every case, sufficient to permit full phenotypic expression of the newly acquired genetic determinants (Table 1). However, the time interval is large enough to permit some change in the proportion of transformant types due to differential selective action against them by the medium. This possibility has been checked by reconstruction experiments using mixtures of transformant types, and, where necessary, as will be discussed below, short-term experiments are conducted to determine the proportions of transformant types found immediately after phenotypic expression. (B) Short-term experiment: in this type of experiment, DNA is allowed to act upon competent recipient bacteria for only a brief interval of time (10-20 min. $=\frac{1}{3}-\frac{2}{3}$ generation time). Competent bacteria are usually obtained by transfer of an inoculum, similar to that described above, into medium 3 containing $0.2 \%(\mathrm{w} / \mathrm{v})$ bovine serum albumin. A volume of $0.1 \mathrm{ml}$. of the appropriate DNA is added at $4 \frac{1}{2}$ to $5 \mathrm{hr}$. after inoculation, and the action of the DNA is terminated by the addition 10-20 min. later of $0 \cdot 1 \mathrm{ml}$. of a $\mathrm{Mg}^{++}$-activated DNase solution (Ravin, 1956). The treated culture is plated either at various hourly intervals after exposure to DNA or at a time (generally $2 \mathrm{hr}$. after exposure) when it is known that phenotypic expression is completed. In a few cases, it was necessary to perform a series of experiments over a period of time with a recipient strain using cultures of reproducible levels of competence. For this purpose, a modification of the 'freezing' technique of Fox \& Hotchkiss (1957) was successfully employed. About $10^{7}$ pneumococci previously grown in medium 3 were inoculated into a flask containing $45 \mathrm{ml}$. of medium 3 plus serum albumin $(0 \cdot 2 \%, \mathrm{w} / \mathrm{v})$ and incubated in a water bath at $37^{\circ}$. At $15 \mathrm{~min}$. intervals during growth, $0.5 \mathrm{ml}$. amounts of the culture are withdrawn and added to a series of tubes containing $1.5 \mathrm{ml}$. of preserving medium, previously chilled in an ice-bath. The contents of each tube is mixed by shaking and immediately frozen in a deep-freeze at $-80^{\circ}$. Preserving medium was prepared by mixing one part of sterile $2 \%$ (w/v) Neopeptone (Difco) containing $10^{-3} \mathrm{M}-\mathrm{CaCl}_{2}$ with one part of sterile $20 \%(\mathrm{w} / \mathrm{v})$ glycerol (sterilized by filtration). One tube from each series prepared in this manner was tested with an active transforming DNA preparation, to determine the level of competence of cells in each series. Those series not possessing sufficiently high levels of competence were discarded; those series containing competent cells retained their high level of competence in the frozen state for at least a few weeks. Frozen recipient cocci to be transformed are thawed in the cold $\left(4-5^{\circ}\right)$, 
and then to $0.2 \mathrm{ml}$. of cell suspension are added $1.8 \mathrm{ml}$. of medium 3 containing $0.2 \%(\mathrm{w} / \mathrm{v})$ serum albumin and $0.1 \mathrm{ml}$. of the desired DNA. The mixture is incubated at $30-32^{\circ}$ (optimal temperature for adsorption of DNA) for $20 \mathrm{~min}$. The DNA is then inactivated by addition of $\mathbf{0} \cdot 1 \mathrm{ml}$. of $\mathrm{Mg}^{++}$-activated DNase. The treated suspension is then incubated at $37^{\circ}$ (optimal temperature for growth) for a period of time sufficient to allow phenotypic expression to occur before assay of the culture.

\section{RESULTS}

Levels of resistance of various mutants and of several recombinant types. The maximum level of erythromycin resistance of each of the five spontaneous mutants was determined by the method of direct plating. The results are recorded in Table 1. It will be noted that the mutation ery-r 6 confers the lowest level of resistance, that the mutations ery-r2, ery-r3 and ery-r 5 confer a similar intermediate level of resistance, and that the mutation ery-ry confers the highest level of resistance. The difference between the ery-r6 level and that of ery-r2 is about tenfold; the difference between the ery-r2 level and that of ery-ry is also roughly tenfold.

Some physiological variability was observed in the maximum level of resistance obtainable by a given strain. This was found in slight differences in the resistance of a given strain using cultures grown at different times. An indication of the extent of the variability is given in Table 1 . The resistances characteristic of the three levels have remained distinct, however, such that, for example, the resistance conferred by a mutation of the intermediate level has never descended as low as the level characteristic of the low level nor risen as high as the level characteristic of the high level.

Table 1 also records the maximum levels of erythromycin resistance possessed by recombinant strains obtained by transformation experiments to be described below. It will suffice to point out here certain antagonistic and synergistic actions between mutations. For example, when the ery-r2 and ery-r 3 mutations are present in the same strain, they confer together about twenty times more resistance than the sum of their individual resistances. When the ery-r 5 mutation is combined with the $e r y-r 2$ and ery-r 3 mutations, the level of resistance of the resulting triply marked bacterium drops by slightly more than half of the level possessed by a strain bearing only the ery-r2 and ery-r3 mutations. Thus, the mutations ery-r2 and ery-r3 are synergistic in combination, whereas the mutation ery-r5 is antagonistic to the action of the ery-r2-r3 combination. The ery-rz mutation, on the other hand, behaves neither synergistically nor antagonistically when recombined with either ery-r5 or ery-r6. The recombinant (possessing both ery-ry and either ery-r5 or ery-r6) exhibits a level of resistance which is indistinguishable from that of the strain bearing only the $e r y-r$ f factor.

Transfer of mutations by DNA-transforming preparations and their behuviour following transfer. The antibiotic-sensitive $\mathrm{Rx}$ strain was transformed in shortand long-term experiments with the DNAs obtained from strains bearing the $s t r-r 1$ mutation and one of the ery-r mutations. The concentration of antibiotic in the plates used to determine the presence of antibiotic-resistant transformants was always considerably less than the maximum level characteristic of the mutation in question. The reason for this procedure was twofold. Some transformants may be 
lost if challenged with the maximum concentration of antibiotic they are genetically capable of withstanding due either to: (1) physiological variability, as a result of which some bacteria in a given culture always possess a lower level of resistance than the average level inherited by the strain, or (2) insufficient time allowed for the phenotypic expression of newly transformed bacteria. The amount of time required for phenotypic expression is measured by the interval between the time of exposure of the recipients to transforming DNA and the time when the fraction of viable bacteria capable of forming colonies in a given concentration of antibiotic reaches a maximum. In this respect, it was found, for example, that the time at which all of the transformants requiring $\operatorname{ery}-r y$ can be recovered depends on the concentration of antibiotic with which the bacteria are challenged. When the challenging concentration of erythromycin was $0.1 \mu \mathrm{g}$. per ml., $3 \mathrm{hr}$. were required to obtain all of the ery-ry transformants. On the other hand, when the challenging concentration was $5 \mu \mathrm{g}$. per ml., over $5 \mathrm{hr}$. of growth were required for all of the ery-ry transformants to be detected. It is entirely possible that the expression of the ery-ry mutation is all-or-none as Fox (1959) found for a streptomycin resistance mutation, but that the probability that an unexpressed transformant will express the phenotype corresponding to its newly acquired genotype is inversely related to the rate of killing, which is greater for higher challenging concentrations of antibiotic. In any event it is clear that, while $3 \mathrm{hr}$. were required for phenotypic expression of the resistance conferred by mutation $e r y-r 7$ to $0 \cdot 1 \mu \mathrm{g}$. erythromycin per ml., only $1 \mathrm{hr}$.

\section{Table 2. Discreteness of transfer of erythromycin resistance mutations in short-term transformation experiments}

1. ery-r6 str-s $1 \times$ DNA ery-r6 str-r 1 ; plated $1 \mathrm{hr}$. after exposure to DNA

\begin{tabular}{|c|c|c|c|c|}
\hline \multirow{2}{*}{\multicolumn{2}{|c|}{$\begin{array}{l}\text { Frequency of transformants producing } \\
\text { colonies in presence of }\end{array}$}} & \multicolumn{3}{|c|}{$\begin{array}{l}\text { Of } 118 \text { colonies tested from } \\
0.075 \mu \mathrm{g} . \text { ery. } / \mathrm{ml} \text {. }\end{array}$} \\
\hline & & \multirow{2}{*}{$\begin{array}{l}\text { No. able } \\
\text { to resist }\end{array}$} & \multicolumn{2}{|c|}{$\mu \mathrm{g}$. ery./ml. } \\
\hline $100 \mu \mathrm{g}$. strep. $/ \mathrm{ml}$. & $0.075 \mu \mathrm{g}$. ery. $/ \mathrm{ml}$ & & $0 \cdot 1$ & 0.25 \\
\hline $1.3 \times 10^{-3}$ & $1.2 \times 10^{-8}$ & $\begin{array}{r}118 \\
0\end{array}$ & $\begin{array}{l}+ \\
+\end{array}$ & $\bar{t}$ \\
\hline
\end{tabular}

2. $e r y-s 7$ str-s $1 \times$ DNA ery-r 7 str-r 1 ; plated $3 \mathrm{hr}$. after exposure to DNA

Frequency of transformants producing colonies in presence of

\begin{tabular}{|c|c|}
\hline $100 \mu \mathrm{g}$. strep. $/ \mathrm{m}$ & $0.05 \mu \mathrm{g}$. ery. $/ \mathrm{r}$ \\
\hline $5.9 \times 10^{-4}$ & $4.5 \times 10^{-4}$ \\
\hline
\end{tabular}

Of 45 colonies tested from $0 \cdot 05 \mu \mathrm{g}$. ery. $/ \mathrm{ml}$.

$\begin{array}{cccc}\begin{array}{c}\text { No. able } \\ \text { to resist }\end{array} & \overbrace{1}^{\mu \mathrm{g} . \text { ery./ml. }} \\ 45 & + & + & 30 \\ 0 & + & - & -\end{array}$

3. $e r y$-s $3 s t r-s 1 \times$ DNA $e r y-r 3 s t r-s 1$; plated $2 \mathrm{hr}$. after exposure to DNA

Frequency of transformants producing colonies in presence of

\begin{tabular}{|c|c|}
\hline $0 \cdot 1 \mu \mathrm{g}$. ery. $/ \mathrm{ml}$. & $5 \cdot 0 \mu \mathrm{g}$. ery. $/ \mathrm{ml}$ \\
\hline $4.5 \times 10^{-3}$ & $<10^{-5}$ \\
\hline
\end{tabular}

Of 120 colonies tested from 5.0 $\mu \mathrm{g}$. ery./ml.

\begin{tabular}{cccc} 
No. able & \multicolumn{3}{c}{$\mu \mathrm{g}$. ery./ml. } \\
to resist & $\overbrace{0 \cdot 1}^{1}$ & 5 \\
120 & + & + & - \\
0 & + & + & + \\
0 & + & - & -
\end{tabular}


was needed for the completion of phenotypic expression of the resistance conferred by mutations ery-r 6 and ery-r 3 to 0.075 and $0.25 \mu \mathrm{g}$. erythromycin per $\mathrm{ml}$. respectively. The time required for expression of the maximal level of resistance that a transformant is genetically capable of withstanding depends, therefore, on the particular ery-r marker being considered (Table 1).

Consequently, when the sensitive Rx strain is treated with the DNA containing the ery-r2 marker, for example, the treated population is challenged with only $\mathbf{0 . 2 5} \mu \mathrm{g}$. erythromycin per ml., although the maximum level of resistance conferred by this marker is four times as great. Furthermore, this challenge is carried out at a time when it is known that all transformants have expressed their ability to resist the challenging concentration of erythromycin (Table 1). The same challenging concentration was found useful for the ery-r 3 and ery-r 5 markers. However, $0.075 \mu$ g. erythromycin per ml. was the challenging concentration used for detecting transformants acquiring the ery-r6 marker, while $0 \cdot 1 \mu \mathrm{g}$. erythromycin per ml. was the concentration used for detecting transformants acquiring the $e r y-r 7$ marker.

In either long- or short-term experiments, it was found that each ery-r marker was transferred as a discrete unit. The only class of antibiotic-resistant transformants detectable was that having the same level of resistance as that of the donor strain. This conclusion is based on the fact that, when $\mathrm{Rx}$ cells treated with DNA bearing a given ery-r marker were challenged by plating in media containing a concentration of erythromycin far below that which the donor strain was capable of resisting, all of the colonies subsequently arising were successfully replicated or streaked on to agar containing the maximum concentration of erythromycin which the donor was capable of resisting, but not on to agar containing a higher concentration. Thus, transformants were not found to possess intermediate or higher levels of resistance than the donor strain. Typical results for the markers ery-r3, ery-r6 and ery-r7 are shown in Table 2.

Table 3. Recombinations between various ery-r mutations

$\begin{array}{cccccc}\begin{array}{c}\text { Mutant } \\ \text { recipient } \\ \text { strain }\end{array} & \overbrace{-r 2} & -r 3 & -r 5 & -r 6 & -r 7 \\ -r 2 & - & -r 2-r 3(40) & - & -r 2-r 6(5) & s 2-r 7(10) \\ -r 3 & -r 2-r 3(40) & - & - & - & s 3-r 7(10) \\ -r 5 & - & - & - & - & r 5-r 7(10) \\ -r 6 & -r 2-s 6(1) & -r 3-s 6(1) & -r 5-s 6(1) & -r 6-r 7(10)\end{array}$

Transformants with increased level of resistance are sought by challenging on agar containing a concentration of erythromycin sufficient to prevent growth of dense populations of recipient strain $(0.25 \mu \mathrm{g} . / \mathrm{ml} .-r 6 ; 5 \mu \mathrm{g} . / \mathrm{ml},-r 2, r 3$ and $r 5)$. Value indicated in parentheses is maximum level of resistance of recombinant. Negative result $(-)$ means that number of colonies observed on agar containing the challenging concentration of erythromycin is no greater than the number arising spontaneously (i.e. in absence of DNA). Indicated genotypes of recombinants are verified in subsequent experiments.

Recombination between mutations. A given mutant may be treated with the DNA extracted from another mutant, and one can determine if transformants are produced having a higher level of resistance than that of the recipient strain. Following long-term exposure of the recipient strain to the particular DNA, one challenges by plating on agar containing a concentration of erythromycin somewhat greater than 
the maximum concentration tolerated by the recipient strain. The actual challenging concentration employed is one just sufficiently high to prevent even slight or feeble growth by dense populations of untreated recipient bacteria spread over the surface of agar. Table 3 records the results of all possible 'crosses' involving the various mutants as donors and the ery-r2, ery-r3, ery-r5 and ery-r6 strains as recipients.

It will be recalled that the $e r y-r 2,-r 3$, and $-r 5$ mutations confer indistinguishable levels of resistance upon a sensitive strain. Although phenotypically similar, however, the three mutations are genotypically distinct. For example, while no mutant strain can be raised in its level of resistance by autologous DNA, recombinants having increased resistance are produced in the 'cross' ery-r2 $\times$ ery-r3. The outcome is identical regardless of how the 'cross' is carried out: mutant ery-r2+ DNA ery-r3, or (the reciprocal 'cross') mutant ery-r3 + DNA ery-r2. Thus, ery-r2 is different from ery-r3. It will be noted that, while the challenging concentration for selecting recombinants in these crosses is $5 \mu \mathrm{g}$. erythromycin per ml., all of the selected transformants are capable of resisting as much as $40 \mu \mathrm{g}$. erythromycin per ml. The mutant ery-r5, on the other hand, when treated with either DNA ery-r2 or DNA ery-r3 did not give rise to cocci with an increased level of resistance to erythromycin. Similarly, neither ery-r2 nor mutant ery-r3 produced cocci with increased resistance when treated with DNA ery-r5. This is presumptive evidence that ery-r 5 is distinct from both $e r y-r 2$ and ery-r3; confirmatory evidence is obtained from experiments to be described below in which ery-5 is raised in its level of resistance by treatment with DNA containing both the ery-r2 and ery-r 3 markers.

When the mutant ery-r6, which has a lower level of resistance than any of the other strains, serves as recipient, one may select for transformants capable of resisting at least the challenging concentration normally employed for detecting transformants acquiring the donor marker, and then one may determine, by subsequent replication or streak-testing, whether any of the colonies growing in the presence of the challenging concentration of erythromycin can grow in the presence of even higher concentrations. Thus, it is found that when, for example, mutant ery-r6 is treated with DNA ery-r2, two classes of transformed pneumococci are obtained: those resisting up to $1 \mu \mathrm{g}$. erythromycin per ml, and, hence, identical to organisms containing ery-r2; and those resisting up to $5 \mu \mathrm{g}$. erythromycin per $\mathrm{ml}$. The latter class is presumed to be the recombinant type ery-r2-r6. The presence of both markers in such bacteria can be proved by experiments described in the next section. It will also be noted that the recombinant type ery-r2-r6 is obtained when mutant ery-r2 is treated with DNA ery-r6 and then challenged with $5 \mu \mathrm{g}$. erythromycin per ml. (Table 3). It is significant, furthermore, that when either mutant ery-r 3 or mutant ery-r 5 is treated with DNA ery-r6, no transformant class can be detected that is capable of resisting a higher concentration of erythromycin than the recipient strain (Table 3 ).

The DNA of mutant ery-ry has been tested on each of the other mutant strains, and in every case, regardless of the ery-r mutation possessed by the recipient strain, transformants enhanced in their level of resistance were detected by plating in agar containing a concentration of erythromycin just sufficiently high to block the growth of untreated recipient bacteria. By streak-testing, it was found that the transformants thus produced exhibited the same phenotype as that of the ery-r7 strain (Table 3). 
Linkage of erythromycin resistance mutations. Having obtained enhancement of resistance by treating one mutant strain with the DNA of another, it was of interest to determine the genetic relationship of the mutations involved in such a cross. When, as in the case of crosses involving ery-r7 mutant as donor, only one transformant class was obtained, corresponding in phenotype to that of the donor, it could be supposed that ery-ry replaces every one of the other mutations in transformation reactions. Further investigation proved, however, that this was not the case. A DNA preparation was made from a single transformant selected in each one of the following crosses: ery-r2 $\times$ ery-r7; ery-r $3 \times$ ery-ry; ery-r $5 \times$ ery-r $r$; $e r y-r 6 \times e r y-r 7$. Two of the DNAs, those prepared from transformants issuing from the former two crosses, behaved as though only the ery-ry mutation was contained in the transformed strain. This was determined by exposing the sensitive Rx strain to the DNA in a short-term experiment and then selecting for bacteria on agar containing $0 \cdot 1 \mu \mathrm{g}$. erythromycin per $\mathrm{ml}$. All of the selected bacteria proved to possess the ery-ry phenotype. However, the DNAs produced from transformants obtained in the latter two crosses produced two classes of resistant bacteria when used to treat the sensitive Rx strain. The phenotype of one of the classes corresponded to that of the $e r y-r^{r}$ strain, but the phenotype of the other class corresponded to that of the other mutant involved (ery-r 5 or ery-r6). For example, in one experiment a transformed strain possessing the phenotype of the ery-ry mutant was selected following a cross between recipient ery-r 5 and donor ery-r\%. The DNA of this selected transformant was prepared and tested in a short-term exposure of the sensitive Rx strain. Cocci capable of producing colonies in the presence of $0 \cdot 1 \mu \mathrm{g}$. erythromycin per ml. were selected. Of 106 such colonies tested, 83 were able to resist a maximum erythromycin concentration of $1 \mu \mathrm{g}$. $/ \mathrm{ml}$. while 23 were able to resist no more than $10 \mu \mathrm{g} . / \mathrm{ml}$. Thus two phenotypic classes were obtained; one corresponding to that of $e r y-r 5-s \%$, the other corresponding to that of either $e r y-s 5-r y$ or ery-r5-r\%. The former class is by far the more abundant. The conclusion to be drawn from the ensemble of these results is that the ery-ry mutation is capable of replacing either the ery-r2 or ery-r3 mutation, but it can combine with either the ery-r6 or ery-r 5 mutation. Whether ery-r7 replaces or combines with another mutation, however, the recombinant possesses the ery-r $r$ phenotype. It is altogether possible that the ery-ry mutation can combine with the ery-r2 and ery-r 3 mutations, but the lack of synergism produced with the ery-ry mutation makes it difficult to determine. If, for example, ery-ry can replace as often as it can combine with one of these mutations, a randomly isolated transformant (obtained in the cross ery-r2, or $e r y-r 3, \times e r y-r 7)$ is just as likely to possess the ery-s2-r7 genotype as the ery-r2-ry genotype. Since further experiments established the linkage of the ery-r2, ery-r3, ery-r 5 and ery-r6 mutations, it is clear that the ery-r7 mutation is linked to all of them.

It will be recalled that enhancement of resistance was obtained in a cross involving the $e r y-r 2$ and $e r y-r 3$ mutations, and in this case the transformed class possessed a maximum level of resistance forty times greater than that of the untreated recipient. In this case, it may be supposed that the transformed strain with the enhanced resistance possesses two mutations, the original mutation of the recipient plus that transferred from the donor via the transforming DNA preparation. Proof that this view is in fact correct may be obtained by extracting the DNA from the trans- 
formant supposedly bearing both mutations (ery-r2 and ery-r3) and then briefly exposing a sensitive strain to this DNA. Three genotypic classes are expected, corresponding to bacteria containing ery-r2 alone, bacteria containing ery-r3 alone, and bacteria containing both ery-r2 and ery-r3. Furthermore, the frequency of transformed bacteria acquiring both mutations relative to the frequency of bacteria acquiring only a single mutant marker provides a means of determining how closely the two mutations are linked.

By this procedure, it has been ascertained that the two mutations are indeed linked, i.e. behave as if borne by the same molecule of transforming DNA. In Table 4 are recorded the results of a typical experiment in which the sensitive $\mathbf{R x}$ strain is treated with DNA from the transformed strain ery-r3-r2 str-r1. It will be noted that the frequency of transformants capable of resisting $0 \cdot 25 \mu \mathrm{g}$. erythromycin per ml. is similar to the frequency of transformants capable of resisting $100 \mu \mathrm{g}$.

Table 4. Classes of transformants produced following short-term exposure of sensitive $R x$ strain to $D N A$ from the presumptive $R x$ ery-r2-r3 str-r1

Period of exposure of competent Rx cells to DNA : $20 \mathrm{~min}$. Period of growth following exposure to DNA: $3 \mathrm{hr}$.

1. Frequency of transformants producing colonies in presence of:

\begin{tabular}{|c|c|c|}
\hline \multicolumn{2}{|c|}{ Erythromycin } & \multirow{2}{*}{$\begin{array}{l}\text { Streptomycin } \\
(100 \mu \mathrm{g} . / \mathrm{ml} .)\end{array}$} \\
\hline $0 \cdot 25 \mu \mathrm{g} . / \mathrm{ml}$ & $5 \mu \mathrm{g} . / \mathrm{ml}$ & \\
\hline $3.9 \times 10^{-4}$ & $5.1 \times 10^{-5}$ & $3.3 \times 10^{-4}$ \\
\hline
\end{tabular}

2. Tests of isolated colonies

$\begin{array}{ccc}\begin{array}{c}\text { Isolated from } \\ \text { agar containing }\end{array} & \begin{array}{c}\text { Capable of growing on } \\ \text { transfer to agar containing }\end{array} & \text { Proportion } \\ 0.25 \mu \mathrm{g} . \text { ery. } / \mathrm{ml} . & 1.0 \mu \mathrm{g} . \text { ery. } / \mathrm{ml} . & 1 \cdot 0 \\ & 5.0 \mu \mathrm{g} \text {. ery. } / \mathrm{ml} . & 1.5 \times 10^{-1} \\ & 100 \mu \mathrm{g} . \text { strep. } / \mathrm{ml} . & 6.9 \times 10^{-8} \\ 100 \mu \mathrm{g} \text {. strep. } / \mathrm{ml} . & 0.25 \mu \mathrm{g} . \text { ery. } / \mathrm{ml} . & 5.8 \times 10^{-3}\end{array}$

3. Further test of 10 colonies

Isolated from agar containing $\mathbf{0 . 2 5} \mu \mathrm{g}$. ery./ml. but incapable of growing at concentrations greater than $1.0 \mu \mathrm{g}$. ery. $/ \mathrm{ml}$.

Number producing transformants capable of resisting $5 \mu \mathrm{g}$. ery./ml. when treated with:

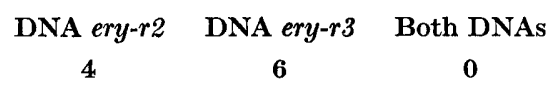

streptomycin per $\mathrm{ml}$. Of the colonies that develop in agar containing $0 \cdot 25 \mu \mathrm{g}$. erythromycin per ml., only about one in $\mathbf{1 5 0}$ is found to be capable of resisting $100 \mu \mathrm{g}$. streptomycin per ml. A similar proportion of colonies that develop in agar containing $100 \mu \mathrm{g}$. streptomycin per $\mathrm{ml}$. is found to be capable of resisting $0 \cdot 25 \mu \mathrm{g}$. erythromycin per ml. This proportion is taken as an index of the frequency of random penetration of competent recipient cocci by two independent ('non-linked' transforming molecules. It will be noted that the frequency of transformants that develop in agar containing $5 \mu \mathrm{g}$. erythromycin per ml. is greater than one-tenth the frequency of transformants that develop in agar containing $0 \cdot 25 \mu \mathrm{g}$. erythromycin per $\mathrm{ml}$. (precisely, the ratio of these two frequencies is $1 \cdot 3 \times 10^{-1}$ ). Similarly, 
if one tests a random sample of colonies that develop in agar containing $0.25 \mu \mathrm{g}$. erythromycin per ml., roughly one in six (precisely, $1.5 \times 10^{-1}$ ) are found to be capable of resisting $5 \mu \mathrm{g}$. erythromycin per ml. The class of transformants capable of resisting $5 \mu \mathrm{g}$. erythromycin per ml., presumably possessing both the ery-r2 and ery-r 3 factors, is obviously occurring more frequently than would be expected on the basis of the random penetration of two independent transforming factors. Furthermore, the maximum level of resistance of this class of transformants, as subsequently determined, was found to be $40 \mu \mathrm{g}$. erythromycin per ml., which is the phenotype of the donor strain. Similarly, it was found that the transformants that cannot resist this high concentration of erythromycin can resist at most $1 \mu \mathrm{g}$. erythromycin per ml., which is the phenotype of either the ery-r2 or ery-r3 strains. It can be shown, moreover, that these transformants are of two genetic types, one corresponding to ery-r2, the other to ery-r3. For example, in the experiment recorded in Table 4, 10 of the transformants appearing in agar containing $\mathbf{0 . 2 5} \mu \mathrm{g}$. erythromycin per ml. that subsequently were found to be unable to resist $5 \mu \mathrm{g}$. erythromycin per ml., were subjected to the following test. One culture of each transformant was treated with DNA ery-r2 str- $r$, and another culture rendered competent under similar conditions was treated with DNA ery-r3 str-r1. Streptomycin resistance transformations were induced in all of the cultures. However, six of the transformants were enhanced in their resistance to erythromycin only when exposed to DNA containing the ery-r3 factor, while four were enhanced only when exposed to DNA containing the ery-r2 factor. The former corresponded, therefore, to cocci containing the ery- $r 2$ factor, while the latter corresponded to cocci containing the ery-r3 factor. Thus, transformants having the ery-r2-s3 and ery-s2-r3 genotypes were recovered in this experiment. In summary, the ery-r2 and ery-r3 factors can be brought together and can be separated by genetic recombination; when together, they behave as though borne by the same molecule of transforming DNA.

Experiments of similar design were carried out to determine the linkage of other pairs of erythromycin resistance markers. For example, linkage of ery-r2 to ery-r6 was demonstrated in the following ways. First of all, long-term exposure of mutant $e r y-r 6$ to DNA containing the factors $e r y-r 2$ and str- $r 1$ reveals that ery-r 6 is apparently replaced by ery-r2 most of the time (Table $5 \mathrm{~A}$ ). That the ery-r2-r6 recombinant occurs is indicated by the existence of a class of transformant that can resist a higher concentration of erythromycin than can ery-r2 ; this class can resist $5 \mu \mathrm{g}-$ erythromycin per $\mathrm{ml}$. The existence of the recombinant is also readily demonstrable by treating mutant ery-r2 with DNA containing the ery-r6 and str-r1 markers (Table 5B). For about 20 transformants acquiring the $s t r-r 1$ factor, one transformant appears that is capable of resisting as much as $\mathbf{5} \mu \mathrm{g}$. erythromycin per $\mathrm{ml}$. The DNA of one such transformant was prepared and used to treat the sensitive $\mathbf{R x}$ $($ ery-s2-s6) strain in a short-term experiment. The results (Table $5 \mathrm{C}$ ) reveal that three phenotypic classes of transformants are obtainable: one corresponding to the ery-r6 phenotype, one corresponding to the ery-r2 phenotype, and one corresponding to the ery-r2-r6 phenotype. The proportions of these classes were found to be approximately $0 \cdot 6: 3: 1$. Repeat experiments have confirmed the interesting finding that the ery-r6-r2 transformant occurs more frequently than the ery-r6-s2 transformant, which is corroborative evidence of the strong linkage of ery-r6 to ery-r2. 
Furthermore, ery-r6 appears to be even more tightly linked to ery-r3. This is revealed by the fact that in five independent long-term experiments in which strain ery-r3 was exposed to DNA containing the factors ery-r6 and str-r1, no transformants were found capable of resisting $5 \mu \mathrm{g}$. erythromycin per ml. although transformants acquiring the str-r1 factor were abundant (Table 6B). Moreover, in the reciprocal cross (strain ery-r6 treated with DNA ery-r3 str-r1) the recombinant ery-r3-r6 also occurred rarely although the replacement of ery-r6 by ery-r 3 occurred

Table 5. Recombination between the mutations ery-r6 and ery-r2

A. Long-term exposure of mutant ery-r6 to DNA ery-r2 str-r1

\begin{tabular}{lccc} 
& \multicolumn{2}{c}{ Frequency of transformants producing colonies in presence of } \\
ery-r6+no DNA & $0.25 \mu \mathrm{g}$. ery./ml. & $5 \mu \mathrm{g}$. ery. $/ \mathrm{ml}$. & $100 \mu \mathrm{g} . \mathrm{strep} . / \mathrm{ml}$. \\
$e r y-r 6+$ DNA & $<10^{-7}$ & $<10^{-7}$ & $<10^{-7}$ \\
$1 \cdot 0 \times 10^{-4} \dagger$ & $3 \cdot 1 \times 10^{-5}$ & $1 \cdot 2 \times 10^{-3}$
\end{tabular}

B. Long-term exposure of mutant ery-r2 to DNA ery-r6 str-r1

\begin{tabular}{|c|c|c|}
\hline & $\begin{array}{r}\text { Frequency of } \\
\text { coloni }\end{array}$ & $\begin{array}{l}\text { formants producing } \\
\text { resence of }\end{array}$ \\
\hline $\begin{array}{l}\text { ery-r2+ no DNA } \\
\text { ery-r2+DNA }\end{array}$ & $\begin{array}{l}5 \mu \mathrm{g} . \mathrm{ery} \cdot / \mathrm{ml} . \\
<10^{-7} \\
1 \cdot 0 \times 10^{-6} \ddagger\end{array}$ & $\begin{array}{c}100 \mu \mathrm{g} . \text { strep. } / \mathrm{ml} . \\
<10^{-7} \\
2.0 \times 10^{-5}\end{array}$ \\
\hline
\end{tabular}

C. Short-term exposure of sensitive Rx strain to DNA ery-r2-r6§

Frequency of transformants producing colonies in presence of

Rx + no DNA

$\mathbf{R x}+$ DNA

Source of colonies: growing in presence of $0.05 \mu \mathrm{g} . / \mathrm{ml}$. $0 \cdot 25 \mu \mathrm{g} . / \mathrm{ml}$. $\mathbf{5} \cdot \mathbf{0} \mu \mathrm{g} . / \mathrm{ml}$.

$\begin{array}{ccc}0.05 \mu \mathrm{g} . \text { ery. } / \mathrm{ml} . & 0.25 \mu \mathrm{g} . \text { ery } / \mathrm{ml} . & 5 \cdot 0 \mu \mathrm{g} . \mathrm{ery} \cdot / \mathrm{ml} . \\ 1.0 \times 10^{-5} & <10^{-5} & <10^{-5} \\ 3.5 \times 10^{-4} & 3.5 \times 10^{-4} & 2 \cdot 4 \times 10^{-5}\end{array}$

Maximum level of resistance $(\mu \mathrm{g}$. ery. $/ \mathrm{mI}$.) of isolated colonies

\begin{tabular}{crccr} 
& \multicolumn{4}{c}{ No. resisting } \\
\cline { 2 - 5 } Total no. tested & $0 \cdot 1$ & $0 \cdot 25$ & 5 & 15 \\
64 & 9 & 41 & 14 & 0 \\
188 & - & 145 & 43 & 0 \\
15 & - & - & 15 & 0
\end{tabular}

$\dagger$ Of 35 colonies isolated all could grow at an erythromycin concentration of $0.25 \mu \mathrm{g} . / \mathrm{ml}$., while 8 could grow at a maximum erythromycin concentration of $5 \mu \mathrm{g} . / \mathrm{ml}$.

† Of 8 colonies isolated, all could grow at a maximum concentration of $5 \mu \mathrm{g}$. ery. $/ \mathrm{ml}$.

$\S$ Source of DNA being strain capable of resisting $5 \mu \mathrm{g}$. erythromycin per $\mathrm{ml}$. obtained in experiment B.

almost as frequently as does the acquisition of the str-r1 marker (Table 6 A,C). The rare ery-r3-r6 recombinant obtained in the reciprocal cross was found to resist as much as $15 \mu \mathrm{g}$. erythromycin per $\mathrm{ml}$. In accord with its presumed genotype, the DNA of the $e r y$-r3-r6 recombinant produces three phenotypic classes in a sensitive recipient strain: one corresponding to the ery-r6 mutant, one corresponding to the ery-r 3 mutant, and one corresponding to the ery-r3-r6 recombinant (Table $6 \mathrm{C}$ ). It is interesting to note, however, that these three classes were produced, respectively, in the proportion 18:1:6. Again, as in the case of the DNA of the ery-r2-r6 recombi- 
nant, the transfer of both mutated sites into the recipient sensitive strain occurred more frequently than did the single transfer of one of the mutated sites. In the present case, however, it was the ery-r 3 mutation that was transferred least frequently, whereas in the previous case it was the ery-r6 mutation that was transferred least frequently.

Table 6. Recombination between the mutations ery-r6 and ery-r3

A. Long-term exposure of mutant ery-r6 to DNA ery-r3 str-r1

\begin{tabular}{|c|c|c|}
\hline & \multicolumn{2}{|c|}{$\begin{array}{l}\text { Frequency of transformants producing } \\
\text { colonies in presence of }\end{array}$} \\
\hline & $0.25 \mu \mathrm{g}$. ery. $/ \mathrm{ml}$ & $100 \mu \mathrm{g}$. strep. $/ \mathrm{ml}$ \\
\hline $\begin{array}{l}\text { ery-r6+ no DNA } \\
\text { ery-r6+DNA }\end{array}$ & $\begin{array}{l}<10^{-6} \\
1 \cdot 1 \times 10^{-5} \dagger\end{array}$ & $\begin{array}{l}<10^{-6} \\
1.9 \times 10^{-5}\end{array}$ \\
\hline
\end{tabular}

B. Long-term exposure of mutant ery-r3 to DNA ery-r6 str-r1

Frequency of transformants producing colonies in presence of

ery-r3+no DNA

ery-r3+DNAt.

$\begin{array}{cc}5 \mu \text { g. ery } / \mathrm{ml} . & 100 \mu \mathrm{g} . \text { strep. } / \mathrm{ml} . \\ <10^{-7} & <10^{-7} \\ <10^{-7} & 3.9 \times 10^{-5}\end{array}$

C. Short-term exposure of sensitive Rx strain to DNA ery-r3-r6\$

Frequency of transformants producing colonies in presence of

$$
\begin{aligned}
& \mathbf{R x}+\text { no DNA } \\
& \mathbf{R x}+\text { DNA }
\end{aligned}
$$

$\begin{array}{ccc}0 \cdot 1 \mu \mathrm{g} . \text { ery. } / \mathrm{ml} . & 0 \cdot 25 \mu \mathrm{g} . \text { ery. } / \mathrm{ml} . & 5 \cdot 0 \mu \mathrm{g} . \text { ery } \cdot / \mathrm{ml} . \\ <10^{-5} & <10^{-5} & <10^{-5} \\ 1 \cdot 7 \times 10^{-4} & 2.9 \times 10^{-5} & <10^{-5}\end{array}$

Maximum level of resistance $(\mu \mathrm{g}$. ery. $/ \mathrm{ml}$.) of isolated colonies

\begin{tabular}{ccccccr} 
Source of colonies: & \multicolumn{5}{c}{ No. resisting } \\
\cline { 2 - 7 } growing in presence of & tested & 0.1 & 0.25 & 5 & 15 & 30 \\
$0.1 \mu \mathrm{g} . / \mathrm{ml}$. & 76 & 55 & 3 & 0 & 18 & 0
\end{tabular}

$\dagger$ Of 52 colonies isolated, 51 could grow at a maximum erythromycin concentration of $1 \mu \mathrm{g} . / \mathrm{ml}$., while 1 could grow at a maximum concentration of $15 \mu \mathrm{g} . / \mathrm{ml}$.

$\$$ Typical result of 5 independent experiments.

$\S$ Source of DNA being strain capable of resisting $15 \mu \mathrm{g}$. erythromycin per ml. obtained in experiment $\mathbf{A}$.

In a similar fashion, it has been determined that the site of the ery-r 5 mutation either overlaps that of ery-r6, or is very closely linked to it. When strain ery-r 5 was treated with DNA ery-r6 str-r1, no transformants were found capable of resisting $5 \mu \mathrm{g}$. erythromycin per $\mathrm{ml}$. (Table $7 \mathrm{~B}$ ). In the reciprocal cross (strain ery-r6 treated with DNA ery-r5 str-r1), transformants capable of resisting $1 \mu \mathrm{g}$. erythromycin per ml. occurred almost as frequently as transformants acquiring the str-r 1 factor (Table 7A). Furthermore, DNA extracted from one of the erythromycinresistant transformants, which are identical in phenotype to ery-r5 cocci, showed in this strain, at least, no evidence of bearing the ery-r6 marker. On the sensitive $\mathbf{R x}$ strain, only one class of transformants was produced, namely, those capable of resisting at most $1 \mu \mathrm{g}$. erythromycin per ml. (Table $7 \mathrm{C}$ ). Thus, the ery-r5 mutation was shown to be capable of replacing the ery-r6 mutation. 
The relation of ery- $r 5$ to ery- $r 2$ and ery- $r 3$. On the basis of the results just discussed, it is possible to conclude:

(1) that the erythromycin resistance mutations ery-r2, $-r 3,-r 5,-r 6$ and $-r 7$ are borne by the same molecule of transforming DNA;

(2) that the sites of the following mutations are separable by genetic recombination: ery-r2 and ery-r3; ery-r2 and ery-r6; ery-r3 and ery-r6; ery-r6 and ery-r7.

(3) that the site of the ery-r6 mutation is very closely linked to the site of the ery-r3 mutation, more so than to the site of the ery-r2 mutation, and it either overlaps or is closely linked to the site of the ery-r5 mutation.

Table 7. Recombination between mutations ery-r6 and ery-r5

A. Long-term exposure of mutant ery-r6 to DNA ery-r5 str-r 1

\begin{tabular}{|c|c|c|}
\hline & \multicolumn{2}{|c|}{$\begin{array}{l}\text { Frequency of transformants producing } \\
\text { colonies in presence of }\end{array}$} \\
\hline & $0.25 \mu$ g. ery. $/ \mathrm{ml}$. & $100 \mu \mathrm{g}$. strep./ml. \\
\hline $\begin{array}{l}\text { ery-r6+ no DNA } \\
\text { ery-r6+DNA }\end{array}$ & $\begin{array}{l}<10^{-6} \\
1 \cdot 4 \times 10^{-5} \dagger\end{array}$ & $\begin{array}{l}<10^{-6} \\
2 \cdot 0 \times 10^{-5}\end{array}$ \\
\hline
\end{tabular}

B. Long-term exposure of mutant ery-r5 to DNA ery-r6 str-r1

\begin{tabular}{|c|c|c|}
\hline & \multicolumn{2}{|c|}{$\begin{array}{l}\text { Frequency of transformants producing } \\
\text { colonies in presence of }\end{array}$} \\
\hline & $5 \mu \mathrm{g}$. ery. $/ \mathrm{ml}$. & $100 \mu$ g. strep. $/ \mathrm{ml}$. \\
\hline $\begin{array}{l}\text { ery-r5 + no DNA } \neq \\
\text { ery-r5 + DNA } \ddagger\end{array}$ & $\begin{array}{l}<10^{-7} \\
<10^{-7}\end{array}$ & $\begin{array}{l}<10^{-7} \\
4 \cdot 4 \times 10^{-5}\end{array}$ \\
\hline
\end{tabular}

C. Short-term exposure of sensitive Rx strain to DNA ery-(r6) r5§

Frequency of transformants producing colonies in presence of $0 \cdot 1 \mu \mathrm{g}$. ery. $/ \mathrm{ml}$.

Rx + no DNA
Rx + DNA

$<10^{-5}$

$5 \cdot 6 \times 10^{-3} \|$

$\dagger$ Of 60 colonies isolated, all were capable of growing at a maximum erythromycin concentration of $1 \mu \mathrm{g} . / \mathrm{ml}$.

$\ddagger$ Typical result of 5 independent experiments.

$\S$ Source of DNA is a strain capable of resisting $1 \mu \mathrm{g}$. ery. $/ \mathrm{ml}$. obtained in experiment A.

II Of 205 colonies isolated, all could grow at a maximum erythromycin concentration of $1 \mu \mathrm{g} . / \mathrm{ml}$.

The relation of the ery-r 5 mutation to the ery-r2 and ery-r 3 mutations is problematic. It was noted that the mutation ery-r5 did not recombine with either $e r y-r 2$ or $e r y-r 3$ to produce a recombinant possessing a significantly greater level of resistance. This fact suggests that either the ery-r 5 mutation recombined with $e r y-r 2$ (or $e r y-r 3$ ) to yield an ery-r2-r5 (or ery-r3-r5) recombinant having no enhanced power of resistance (or else a lower level of resistance), or that the ery-r 5 mutation is allelic to the ery-r2 and ery-r3 mutations in overlapping both of them. The first evidence bearing on this question suggested that the former explanation is correct. When the mutant bearing the ery-r5 mutation was treated with DNA from a strain containing the ery-r2-r3 and str-r1 markers, two classes of erythromycin-resistant transformants were recovered in agar containing $5 \mu \mathrm{g}$. erythromycin per ml. : a class the maximum level of resistance of which was $15 \mu \mathrm{g}$. erythromycin per ml., and a 
class the maximum level of resistance of which was about $40 \mu \mathrm{g}$. erythromycin per ml. The former was considerably more frequent, since nine of eleven independent transformants belonged to this class. On the contrary, when the ery-r2 or ery-r 3 mutant was treated with this DNA, the only class of transformants recovered was one capable of resisting a maximum of $40 \mu \mathrm{g}$. erythromycin per ml. This class corresponds to the expected ery-r2-r3 recombinants. These findings demonstrated that the mutation $e r y-r 5$ was indeed distinct from bothery-r2 and ery-r3. They indicate, moreover, that the replacement of ery-r 5 by ery-r2-r 3 occurred less frequently than recombination. between ery-r5 and ery-r2-r3. The phenotype of the presumed ery-r2-r3-r5 recombinant has a lower level of resistance than that of the ery-r2-r3 donor, and it is therefore suggestive that the mutation $e r y-r 5$ in conjunction with either ery-r2 or ery-r3 had a lower level of resistance than a mutant bearing only one of the muta-

Table 8. Short-term exposure of $R x$ ery-s2-s3-s5 str-s1 to DNA ery-r2-r3-r5 str-r1

A. Frequency of transformant classes as a function of time following exposure to DNA

Incubated cells in presence of albumin for $4 \mathrm{hr} .10 \mathrm{~min}$.; added DNA for $20 \mathrm{~min}$. ; added

DNase; then plated at hourly intervals.

Time after addition of DNase ...

$1 \mathrm{hr}$.

2 hr.

$3 \mathrm{hr}$.

$4 \mathrm{hr}$.

Total no. cocci per $\mathrm{ml}$.

Freq. of transformants producing

$1.5 \times 10^{6}$

$5 \cdot 1 \times 10^{6}$

$2 \cdot 3 \times 10^{7}$

$8.9 \times 10^{7}$

colonies in $100 \mu \mathrm{g}$. strep./ml.

Freq. of transformants producing

$5.2 \times 10^{-6}$

$6 \cdot 3 \times 10^{-6}$

$4.1 \times 10^{-6}$

$4.7 \times 10^{-6}$

colonies in $0.25 \mu \mathrm{g}$. ery. $/ \mathrm{ml}$.

Freq. of transformants producing

$7 \cdot 1 \times 10^{-6}$

$1 \cdot 2 \times 10^{-5}$

$5 \cdot 7 \times 10^{-6}$

$1 \cdot 0 \times 10^{-5}$

colonies in $5 \mu \mathrm{g}$. ery. $/ \mathrm{ml}$.

$\underline{6.6 \times 10^{-7}} \quad 1.2 \times 10^{-6} \quad \underline{1.0 \times 10^{-7}} \quad 7.6 \times 10^{-7}$

(Underlining means frequency determination is based on colony count of $<10$.)

B. Test of $s t r-r$ transformants selected on $100 \mu \mathrm{g}$. strep. $/ \mathrm{ml}$.

Total no. colonies tested:

Total no. colonies that can resist at least $0.25 \mu \mathrm{g}$. ery. $/ \mathrm{ml}$.

Proportion of str-r transformants that can resist ery.

621

3

$4.8 \times 10^{-3}$

C. Test of ery-r transformants selected on $0 \cdot 25 \mu \mathrm{g}$. ery. $/ \mathrm{ml}$.

Total no colonies tested:

Total no. colonies that can resist at least $5 \mu \mathrm{g}$. ery. $/ \mathrm{ml}$.

Proportion of ery- $r$ transformants that can resist $5 \mu \mathrm{g}$. ery. $/ \mathrm{ml}$.

Total no. of ery-r transformants found to resist at least $5 \mu \mathrm{g}$. ery. $/ \mathrm{ml}$.

No. of these transformants found to resist at most $15 \mu \mathrm{g}$. ery./ml.

No. of these transformants found to resist at most $40 \mu \mathrm{g}$. ery. $/ \mathrm{ml}$.

714

94

$1.3 \times 10^{-1}$

94

94

0

15

14

1

Total no. colonies resistant to at most $15 \mu \mathrm{g}$. ery. $/ \mathrm{ml}$

Total no. colonies resistant to at most $40 \mu \mathrm{g}$. ery. $/ \mathrm{ml}$.

E. Analysis of 24 ery- $r$ transformants incapable of resisting $5 \mu \mathrm{g}$. ery./ml.

No. of transformants enhanced in erythromycin resistance:

by exposure to DNA ery-r2 str-r1, but not to DNA ery-r3 str-r1

by exposure to DNA ery-r3 str-r1, but not to DNA ery-r2 str-r1 by exposure to neither DNA

* 2 ; transformants further tested; genotypes of both: ery-r3-r5.

$* * 7$; transformants further tested; genotypes of all: ery-r2-r5. 
tions. This hypothesis would account for the absence of transformants enhanced in their level of resistance when the mutant bearing the ery-r 5 marker is crossed with a mutant bearing either the ery-r2 or ery-r3 marker.

An investigation was undertaken of the DNA extracted from one of the presumed ery-r2-r3-r5 recombinants (i.e. a transformant resisting at most $15 \mu \mathrm{g}$. erythromycin per ml.) into which the $s t r-r 1$ marker was subsequently transferred. The sensitive Rx strain was exposed to this DNA in a short-term experiment. If ery-r 5 is separable by recombination from ery-r2 and ery-r3, then one should expect to recover the following genotypic products: ery-s2-s3-r5, ery-r2-s3-s5, ery-s2-r3-s5. In addition of course, genotypes containing two, and even three, mutant markers should be produced. The actual results obtained reveal a more complex situation (Table 8). Transformants capable of resisting at most $1 \mu \mathrm{g}$. erythromycin per ml. occur about six times more frequently than transformants capable of resisting a higher concentration of erythromycin (Table $8 \mathrm{~A}$ ). The vast majority of the latter are phenotypically identical to the donor strain (i.e. ery-r2-r3-r5), which resists at most $15 \mu \mathrm{g}$. erythromycin per ml. (Table $\mathbf{8 C}$ ). Transformants capable of resisting $40 \mu \mathrm{g}$. erythromycin per ml. (i.e. corresponding to the genotype ery-r2-r3-s5) are rare, but have occasionally been detected (Table $8 \mathrm{D}$ ). Incidentally, the relatively high frequency of joint transfer of the ery-r2,-r3, and $-r 5$ factors is corroborative evidence of the linkage of these three factors (Table $8 \mathrm{~B}, \mathrm{C}$ ). As for the transformants capable of resisting only a low concentration of erythromycin, they were subjected to further analysis (Table $8 \mathrm{E}$ ). They were first isolated and grown in medium 3. Samples from the same competent culture of a given isolated transformant were then exposed separately to DNA ery-r2 str-r1 and to DNA ery-r3 str-r1. These treated cultures were then challenged on agar containing $5 \mu \mathrm{g}$. erythromycin per ml. and on agar containing $100 \mu \mathrm{g}$. streptomycin per ml. The appearance of a significant number of colonies in streptomycincontaining agar reveals that the DNAs are active and that the cultures were competent when exposed to the DNAs. In every case where these conditions were fulfilled, a significant number of colonies appeared on agar containing $5 \mu \mathrm{g}$. erythromycin per ml. as a result of exposure to either the DNA bearing the ery-r2 marker or to the DNA bearing the ery-r3, but not both. Thus, among the transformants resisting a low concentration of erythromycin obtained in the original treatment of the sensitive Rx strain with DNA ery-r2-r3-r5 str-r1, the genotype ery-s2-s3-r5 is rare, if it occurs at all. These transformants could have, however, one of the following genotypes : ery-r2-s3-s5, ery-s2-r3-s5, ery-s2-r3-r5, ery-r2-s3-r5. Bacteria having one of the latter two genotypes could possibly have the same level of resistance as bacteria having one of the former two genotypes, as mentioned above. However, bacteria having the genotype ery-r2-s3-r5 could be distinguished from those having the genotype ery-r2-s3-s5 by the fact that the latter would produce recombinants capable of resisting $40 \mu \mathrm{g}$. erythromycin per ml. following exposure to DNA ery-r3, whereas the former would produce recombinants capable of resisting at most $15 \mu \mathrm{g}$. erythromycin per $\mathrm{ml}$. In a similar fashion, bacteria possessing the genotype ery-s2-r3-s5 could be distinguished from those possessing the genotype ery-s2-r3-r5 by determining the level of resistance of recombinants produced following exposure to DNA ery-r2. Therefore, following the exposure to DNA ery-r2 and to DNA ery-r3 the colonies appearing in agar containing $5 \mu \mathrm{g}$. erythromycin per $\mathrm{ml}$. were isolated and tested for their maximum level of resistance. The outcome of such an analysis 
(Table $8 \mathrm{E}$ ) reveals that the transformants capable of resisting only a low concentration of erythromycin are of the following genotypes, in the proportions indicated: 3 ery-r2-s3-r5, 1 ery-s2-r3-r5. The ery-r2-s3-s5 and ery-s2-r3-s5 genotypes apparently occur infrequently.

The principal conclusion to be drawn from this study, therefore, is that the ery-r5 mutation once linked to the ery-r2 and ery-r3 mutations by genetic recombination can be separated from those mutations only with great difficulty. The surprising finding is that the association of ery-r5 with ery-r2-r3 occurs considerably more frequently than would be expected from the rarity of dissociation of ery-r 5 from ery-r2-r3. A number of attempts have been made to eliminate the ery-r5 mutation from the ery-r2-r3-r5 strain by replacing it with its ery-s5 allele. This was done by long-term exposure of the strain to each of the following DNAs : ery-s2-s3-s5 str-r1, ery-r2-s3-s5 str-r1, ery-s2-r3-s5 str-r1, ery-r2-r3-s5 str-r1, and by challenging samples of the treated strain with $40 \mu \mathrm{g}$. erythromycin per ml. or $100 \mu \mathrm{g}$. streptomycin per $\mathrm{ml}$. Although acquisition of the $\operatorname{str}-r 1$ marker could be demonstrated, no recombinants having the ery-r2-r3-s5 genotype could be detected by this method. One may conclude either that a challenge of $40 \mu \mathrm{g}$. erythromycin per ml. is too great for $e r y-r 2-r 3-s 5$ transformants to withstand only a few generations after transformation, or that replacement, within the ery-r2-r3-r5 complex, of the ery-r5 mutated site by the corresponding unmutated allele is extremely rare. The latter explanation seems more likely, since some ery-r2-r3-s5 transformants can be detected in longterm experiments in which sensitive $\mathrm{Rx}$ cocci (ery-s2-s3-s5) are treated with DNA ery-r2-r3-s5 and challenged with $40 \mu \mathrm{g}$. erythromycin per ml. It is true, however, that the recovery of such transformants is more efficient when a lower challenging concentration of erythromycin is used.

Reversions of the ery-r3 and ery-r5 mutations. In the periodic transfer of stock mutant cultures, it was noted that certain mutants often reverted to the wild-type (erythromycin-sensitive) condition. This was noted when samples of the cultures were plated on plain agar and on agar containing a concentration of erythromycin which the originally isolated mutants were able to resist. A far greater number of colonies appearing on plain agar than on erythromycin agar suggested that reversions had occurred and had been selected for. That this was indeed the case was shown by the fact that a large proportion of the colonies appearing on plain agar were identical to wild-type in their level of resistance to erythromycin, and that the cocci in such colonies (or in wild-type cultures) had a slight but definite selective advantage when mixed with the original mutant type and grown in media in the absence of erythromycin. The most commonly reverting mutant cultures were those of ery-r 3 and ery-r 5 . The mutation ery-r2 was very stable, and indeed, no case of a reversion has been noted despite numerous transfers of several different clones bearing this marker during the more than 2 years in which this marker has been studied. Furthermore, the mutant culture ery-r2-r3 often drops in its level of resistance from 40 to $1 \mu \mathrm{g}$. erythromycin per ml.; but when it does so, it is found that the mutation at the ery-r3 site has reverted, while the mutation at the ery-r2 site has persisted. The method of determining the site of reversion will be described below. It should be stated at this point, however, that despite the known revertibility of the ery-r3 and ery-r5 mutations, the recombinant ery-r2-r3-r5 is quite stable. A search for a reverted type having the genotype ery-r2-r3-s5, having a higher level of resistance 
than the triply mutant type, has been fruitless. Finally, it should be stated that at least in the routine inspection of transferred stocks, the ery-r6 and ery-ry mutations have not been found to undergo reversions to the wild-type condition.

There are essentially four possibilities of accounting for a reversion in one of the erythromycin-resistant strains. The first possibility is that a true back-mutation occurs, in the sense that the mutated site of the DNA molecule reverts to the original physico-chemical configuration that existed in the parental wild-type erythromycin-sensitive strain. The second possibility is that, in a reversion, the mutated site undergoes a change in physico-chemical configuration, which is not to that of the parental wild-type molecule but which, nevertheless, confers the same sensitivity to erythromycin as does the wild-type configuration. For reasons to be discussed below, it is not easy to distinguish experimentally between these first two possibilities, and therefore the term 'back-mutation' will be applied to both in the sense of referring to involvement of the mutated site in reversion. The third possibility is that, in a reversion, a suppressor mutation arises linked to the site of the erythromycin resistance mutation, and as a consequence, the resistance normally conferred by the latter is suppressed. The fourth possibility is similar to the third, except that the suppressor is unlinked to the erythromycin resistance mutation. For singly marked ery-r 3 and ery-r 5 mutants, the third and fourth possibilities may be tested: $(a)$ by treating one of the reverted strains with the DNA of the wildtype sensitive Rx strain, and conversely, $(b)$ by treating the wild-type strain with DNA extracted from a reverted strain. In either cross, erythromycin-resistant transformants should appear having the phenotype of the original (unreverted) mutant strain, if a suppressor mutation is the cause of the phenotypic reversion to wild-type. In $(a)$ the wild-type allele of the suppressor should replace its suppressing homologue in the reverted strain, whereas in $(b)$ the intact erythromycin resistance mutation should be able to be transferred away from its suppressor into the recipient sensitive strain. If the suppressor is linked to the erythromycin resistance mutation, the frequency of erythromycin-resistant transformants would be expected to be lower than in the case where it is unlinked. The spontaneous rate of mutation to erythromycin resistance $\left(10^{-8}\right.$ to $\left.10^{-9}\right)$ sets a lower limit to the frequency of separation of the suppressor from the ery-r mutation than would be detectable.

For doubly marked mutants (ery-r2-r3), the third and fourth possibilities of explaining reversions may be tested in another way. The reversions that occurred in the ery-r2-r3 cultures were able to resist $1 \mu \mathrm{g}$. erythromycin per ml., although the parental culture could withstand $40 \mu \mathrm{g}$. erythromycin per ml. If a suppressor arose to counteract one of the mutated sites (ery-r2 or ery-r3), then the level of resistance characteristic of the ery-r2-r3 strain should be reconstituted by exposure to both the DNA of the normal (i.e. unsuppressed) ery-r2 strain and the DNA of the normal ery-r3 strain. For the suppressor should be replaced by its wild-type homologue in either case. On the contrary, if one of the sites had undergone a 'back-mutation', the enhanced level of resistance can be reconstituted only by exposure to one of these DNAs, namely, the DNA bearing the mutation lost in the reverted strain. Eleven independent reversions in $\operatorname{ery}-r 2-r 3$ strains were selected. Competent cultures of these reversions were tested by exposing samples separately to DNA ery-r2 str-r1 and to DNA ery-r3 str-r1. Streptomycin resistance transformations were induced readily. However, transformants capable of resisting $5 \mu \mathrm{g}$. erythromycin per ml. were obtained only after exposure to DNA containing the 
ery-r3 marker. Although the frequency of transformation to a high level of resistance induced by the ery-r3 marker was as high as $10^{-4}$, the frequency of such transformations by the ery-r 2 marker was less than $10^{-8}$. These results permit the conclusion that the ery-r2 mutation was not involved in these reversions, and that in each case the ery-r 3 mutation underwent a 'back-mutation' to the original wild-type condition.

The results observed in the reversions of the ery-r2-r3 strains encouraged further analysis of reversions in ery-r3 and in ery-r 5 strains in order to determine whether suppressor mutations could account for any of these reversions. Five independent reversions in strains bearing the ery-r 5 marker and five independent reversions in strains bearing the ery-r 3 marker were tested by the procedure described in the previous paragraph. Similarly, a reversion in the E21 strain and one in the E24 strain were tested. The DNA used in a given cross always contained, in addition, either the $s t r-r 1$ mutation or the $c a p s^{+}$marker, so that negative findings with respect to the induction of erythromycin resistant transformants were always controlled by positive transfer of some unlinked marker. The results were uniformly negative with respect to the production of erythromycin resistant transformants : such transformants did not appear at a frequency greater than that at which spontaneous mutations arise. Consequently, it may be concluded that most of the reversions in $e r y-r 3$ and $e r y-r 5$ strains are due to back-mutations in the sense just described or to suppressor mutations occurring at sites so closely linked to the original mutated sites that separation by genetic recombination occurs with an undetectably low frequency.

One means exists for distinguishing between the first two possibilities for explaining reversions. If a given erythromycin resistance mutation involved a sufficiently large region of the DNA molecule, and if the reversion resulted in a diminution of the mutated region, and if different reversions caused different non-overlapping portions of the originally mutated site to persist, it may be possible to reconstitute an erythromycin-resistant strain by a 'cross' between two reverted strains. This possibility was examined by means of 'crosses' between a number of reverted strains as shown in Table 9. In no case, however, was resistance to erythromycin recon-

Table 9. Attempts to reconstitute erythromycin resistance by crosses between reverted ery-r strains

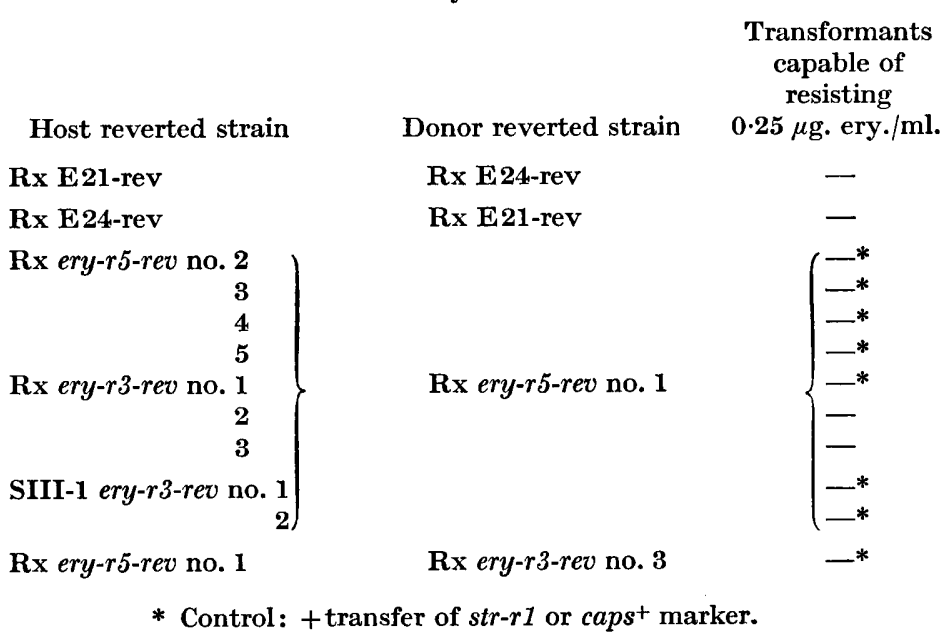


stituted. This finding does not rule out the second possibility of explaining reversions but it does make improbable the assumption of diminution of mutation in a reversion.

\section{DISCUSSION}

The molecule of pneumococcal DNA which regulates resistance to erythromycin is apparently distinct from other molecules of pneumococcal DNA which regulate such diverse properties as capsule synthesis, resistance to streptomycin, etc., in the sense that its transfer in transformation reactions is independent of the transfer of the others (Ravin, 1960). This finding is generally interpreted as due to a heterogeneity in the species of DNA molecules contained in a given genome (Hotchkiss, 1951). In any case, it is evident that whatever organelle organizes the DNA content of a bacterium, extraction of the DNA liberates DNA molecules of different kinds into a heterogeneous mixture. It is hoped that future biochemical investigations will reveal the chemical and/or physical differences between these molecules. In addition to the differences between molecules, however, there is evident intramolecular heterogeneity. A molecule affecting a given bacterial function is differentiable into regions having discrete quantitative influences of their own and capable of being separated from each other or brought together by genetic recombination (EphrussiTaylor, 1951; Hotchkiss \& Evans, 1958; Ravin, 1960; Lacks \& Hotchkiss, 1960). The results obtained with the molecule governing erythromycin resistance in pneumococcus supply further evidence in this regard. Current conceptions of the structure of the DNA molecule equate these different regions within the molecule to specific sequences of nucleotides in the linear DNA polymer.

Although they demonstrate the linkage of the five erythromycin resistance mutations, the present experiments are insufficient to determine the precise locations of these mutations with respect to each other. Further investigations are currently in progress with the aim of clarifying their spatial relationship. Nevertheless, the work reported at this time describes certain anomalous situations which appear to be of considerable interest for our understanding of intramolecular recombination (Ravin, 1961). These situations include the following:

(1) The frequency of recombination between given sites on the endogenous (host) and transforming (donor) DNA molecules appears to vary according to the genetic composition of the recombining molecules. When, for example, the sensitive parental strain ery-s2-s3-s5 is exposed to the triply-marked DNA from the recombinant ery-r2-r3-r5, the most frequent classes of transformants produced are ery-r2-s3-r5, ery-s2-r3-r5 and ery-r2-r3-r5. In other words, the ery-r5 mutation tends to be transferred along with one or both of the other mutations. Such a result would be readily explained on the grounds that the ery-r5 mutation lies between the ery-r2 and ery-r3 mutations, so that a double 'cross-over' within a limited segment of the DNA molecule would be necessary to free ery-r 5 from the mutations on either side of it. Such a double 'cross-over' may be expected to occur infrequently. On this hypothesis, when the ery-s2-s3-r5 mutant is treated with DNA from the recombinant ery-r2-r3-s5, the transformant ery-r2-r3-s5 should be produced more frequently than the transformant ery-r2-r3-r5 which would require the same type of double 'cross-over' as has just been invoked. On the contrary, however, the ery-r2-r3-r5 recombinant is the more frequent product in this cross. Similarly, to take another example, when ery-r3 is crossed with ery-r6, the recombinant ery-r3-r6 is rare. On the other hand, when ery-s3-s6 is treated with DNA ery-r3-r6, the frequency of the 
recombinant ery-s3-r6 is relatively high. Yet in all respects, except for the specific nature of the sites being confronted in these crosses, the recombinations involved are similar. These results are probably similar to those of Lacks \& Hotchkiss (1960), who obtained quite different recombination frequencies in reciprocal crosses between 'maltase' mutants in pneumococcus. It is possible that all of these anomalous results in transformation-mediated recombinations may be eventually explicable by a model, like that discussed by Ephrussi-Taylor (1961), in which the relative lengths of the mutated sites, as well as the distances between them, influence the frequency of recombination.

(2) When the sensitive ery-s2-s3-s6 strain is treated either with DNA from the recombinant ery-r2-s3-r6 or with DNA from the recombinant ery-s2-r3-r6, the transfer of the two resistance mutations occurs more frequently than the transfer of a specific single mutation. In the case of DNA ery-r2-s3-r6, it is ery-r6 that is transferred rarely relative to the transfer of ery-r2-r6. In the case of DNA ery-s2-r3$r 6$, it is ery-r3 that is transferred rarely relative to the transfer of ery-r3-r6. At the present time, it is premature to formulate a model to account for these results. It is interesting, nevertheless, that these two cases provide exceptions to the general rule that a linked pair of mutations is transferred less frequently than the individual mutations (for review, see Ravin, 1961).

Obviously, more crosses need to be conducted using all possible combinations of donor and recipient genotypes. Such experiments are in progress. The results of these further studies should throw light, not only upon the unusual situations described above, but also on the order of the mutated sites in the molecule of DNA governing resistance to erythromycin. It is worth remarking, however, that all five independent spontaneous mutations to erythromycin resistance have been shown to be transferred by the same molecule of DNA. This finding is in support of the possibility, outlined by Bryan (1961), that the different genetic factors known to underlie multi-step resistance to antibiotics are not unlinked polygenes, but rather closely linked members of a complex locus. The action of the latter, as in Bryan's studies on streptomycin resistance, may be affected by modifier genes, which do not confer any resistance by themselves.

Many previous genetic studies of micro-organisms and viruses have indicated the occurrence of what we have referred to above as 'back-mutations', i.e. reversemutations occurring at or extremely close to the original sites of mutation. Thus, it is not surprising to find further evidence of such alterations with the genetic material of pneumococci. Since, however, individual DNA molecules are the vectors of genetic transfer in transformation reactions, one has the unique opportunity of localizing the site of the 'back-mutation', not only in terms of genetic (recombination) distances, but also in particular regions of specific DNA molecules. One knows at least, from the present studies, that a 'back-mutation' may occur on the same molecule of DNA as that of the original mutation, and, indeed, may occur so close to the site of the latter as to be inseparable from it by genetic recombination. The question as to whether a 'back-mutation' always restores the original configuration of the genetic material is an interesting one, and is open to analysis. It may be possible to find at some time that a cross between two reversions restores a mutant condition, although our preliminary attempts in this regard have been uniformly negative. If such a positive case were found, evidence would be provided for the existence of different 'wild-type' states of genetic material.

The phenotypic interactions of the different mutations probably reflect the 
functional differentiation of the genetic locus concerned with erythromycin resistance. It has been noted that two different mutations of the ery locus often interact to produce a more-than-additive, or synergistic, enhancement of resistance to erythromycin. However, this is not always the case. The ery-r5 mutation does not add appreciably to the level of resistance of a strain already bearing the ery-r2 or ery-r3 mutation. Moreover, it antagonizes the action of the ery-r2-r3 duplex. Finally, the $e r y-r 7$ mutation does not cause any synergistic effect when coupled with either ery-r6 or ery-r5. While it is altogether possible that $e r y-r 7$ is epistatic to $e r y-r 6$ and ery-r5, this cannot be readily determined from the present data since the sum of the effects of $e r y-r 7$ and $e r y-r 5$ (which would confer a maximum level of resistance of $11 \mu \mathrm{g}$. erythromycin per ml.) is indistinguishable from an epistatic effect of ery-ry (which would confer a maximum level of resistance of $10 \mu \mathrm{g}$. per ml.). New experiments are being planned to test the possible epistasis of the ery-r7 mutation. It appears likely, in any event, that $e r y-r^{\prime} /$ acts physiologically in a different manner from that of the other mutations, because of its unique rate of phenotypic expression. Unfortunately, as yet little is known of the biochemical mechanism of erythromycin resistance. No enzymic activity capable of destroying erythromycin has been found in cultures of several different species of erythromycin resistant bacteria (Haight \& Finland, 1952 $a$ ). On the other hand, the inhibitory action of erythromycin against the diphtheria bacillus is known to be antagonized by pantothenic acid, $\beta$-alanine and L-carnosine (Brown \& Emerson, 1953). This finding is suggestive of a specific metabolic block produced by the antibiotic and furnishes a means of determining the mode of resistance to erythromycin. With such information in hand, it would be of considerable interest to relate the observed epistatic, antagonistic and synergistic interactions of the erythromycin resistance mutations to the specific biochemical functions they carry out in conferring resistance upon the pneumococcus. In an elegant study by Hotchkiss \& Evans (1958), the action of three closely linked mutations conferring resistance to sulphanilamide could be ascribed to specific modifications they imparted to the substrate-binding capacity of an enzyme involved in folic acid synthesis. Such studies provide a powerful means of investigating the relation of genetic fine structure to enzyme structure and activity.

Various stages of this research benefited from the able technical assistance of Mrs Jane Garnham.

This research was supported by research grant E-727 awarded to the senior author by the National Institute of Allergy and Infectious Diseases, United States Public Health Service.

\section{REFERENCES}

Benzer, S. (1955). The fine structure of a genetic region in bacteriophage. Proc. nat. Acad. Sci., Wash. 41, 344.

Brown, R. G. \& Emerson, G. A. (1953). In vitro antagonism of pantothenic acid, $\beta$ alanine and L-carnosine to inhibitory effects of erythromycin upon the growth of Corynebacterium diphtheriae. Fed. Proc. 12, 304.

Bryan, B. (1961). Genetic modifiers of streptomycin resistance in Pneumococcus. J. Bact. (in the Press).

Demerec, M. (1945). Production of Staphylococcus strains resistant to various concentrations of penicillin. Proc. nat. Acad. Sci., Wash. 31, 16.

Demerec, M. (1956). A comparative study of certain gene loci in Salmonella. Cold Spr. Harb. Symp. quant. Biol. 21, 113. 
Ephrati-Elizur, E., Srinivasan, P. R. \& Zamenhof, S. (1961). Genetic analysis, by means of transformation, of histidine linkage groups in Bacillus subtilis. Proc. nat. Acad. Sci., Wash. 47, 56.

Ephrussi-Taylor, H. E. (1951). Transformations allogènes du Pneumocoque. Exp. Cell Res. $2,589$.

EPHRUSSI-TAYLOR, H. E. (1961). Recombination analysis in microbial systems. In Growth; Molecule, Cell, Organism. New York: Basic Books.

Fox, M. (1959). Phenotypic expression of a genetic property introduced by deoxyribonucleate. J. gen. Physiol. 42, 737.

Fox, M. \& Hotchkiss, R. D. (1957). Initiation of bacterial transformation. Nature, Lond. 179, 1322.

Goodgal, S. H. \& Herriot, R. M. (1957). A study of linked transformations in Hemophilus influenzae. Rec. Genet. Soc. Amer. 26, 272.

GreEn, D. McD. (1957). The transformation of resistance to erythromycin in Diplococcus pneumoniae. Microb. Genet. Bull. 15, 13.

GreEN, D. MCD. (1959). A host-specific variation affecting relative frequency of transformation of two markers in Pneumococcus. Exp. Cell. Res. 18, 466.

Haight, T. H. \& Finland, M. (1952a). The antibacterial action of erythromycin. Proc. Soc. exp. Biol., N.Y. 81, 175.

Haight, T. H. \& Finland, M. (1952b). Resistance of bacteria to erythromycin. Proc. Soc. exp. Biol. N.Y. 81, 183.

Haight, T. H. \& Finland, M. (1952 c). Observations on the mode of action of erythromycin. Proc. Soc. exp. Biol. N.Y. 81, 188.

HотснкIss, R. D. (1951). Transfer of penicillin resistance in pneumococci by the deoxyribonucleate derived from resistant cultures. Cold Spr. Harb. Symp. quant. Biol. 16, 457.

Hoтchiss, R. D. \& Evans, A. H. (1958). Analysis of the complex sulfonamide resistance locus of Pneumococcus. Cold Spr. Harb. Symp. quant. Biol. $23,85$.

Hotchkiss, R. D. \& Marmur, J. (1954). Double marker transformations as evidence of linked factors in deoxyribonucleate transforming agents. Proc. nat. Acad. Sci., Wash. 40, 55.

Lacks, S. \& Hotchкiss, R. D. (1960). A study of the genetic material determining an enzyme activity in Pneumococcus. Biochim. biophys. Acta, 39, 508.

Lederberg, J. \& Lederberg, E. M. (1952). Replica plating and indirect selection of bacterial mutants. J. Bact. 63, 399.

Ponteconvo, G. (1952). Genetical analysis of cell organization. Symp. Soc. exp. Biol. 6, 218.

Pritchard, R. H. (1955). The linear arrangement of a series of alleles in Aspergillus nidulans. Heredity, 9, 343.

Ravin, A. W. (1956). The properties of bacterial transforming systems. Brookhaven Symp. Biol. 8, 33.

Ravin, A. W. (1959). Reciprocal capsular transformations of pneumococci. J. Bact. 77, 296.

Ravin, A. W. (1960). Linked mutations borne by deoxyribonucleic acid controlling the synthesis of capsular polysaccharide in pneumococcus. Genetics, $45,1387$.

Ravin, A. W. (1961). The genetics of transformation. Advanc. Genet. 10, 61 . 